\title{
STUDI PENGGUNAAN OBAT DIARE PADA ANAK PASIEN RAWAT INAP DI RSUD ANDI DJEMMA MASAMBA KABUPATEN LUWU UTARA PERIODE JANUARI-DESEMBER 2014
}

\author{
Irma santi, Hendra Herman,Dian Dwi Aninditia \\ Fakultas Farmasi Universitas Muslim Indonesia, Makassar \\ Email: irma.santi@umi.ac.id
}

\begin{abstract}
Diarrhea is generally caused by the bacteria contamined in food and drink. If the bacteria are not the right treatment, it can be fatal and cause death. This research aimed to present the drug use on the diarrhea patient of hospitalized children ar RSUD Andi Djemma Masamba North Luwu district. This research used descriptive method by collecting data retrospectively. The data were collected by searching the treatment records given by doctors to diarrhea patient of hospitalized children. The data obtained included patient medical record number, sex, age, body temperature, therapy (drug name, dose, frequency, route of administration) and length of stay. The result showed that the diarrhea drug use on children included antibiotic drugs(cotrimoxazole 4,3\%, amoxicillin 2,9\%, gentamicin 4,3\%, cefotaxime $1.4 \%$ ) antimicrobial (metronidazole 14,5\%) zinc supplements 30,4\%,probiotics 2,9\%, antipyretics (paracetamol 34,8\%) antiemetic (methoclopramide 1,5\%) and antidispepsia (omeprazole 2,9\%).
\end{abstract}

Key words : Diarrhea, Children, RSUD Andi Djemma Masamba.

\section{PENDAHULUAN}

Diare adalah buang air besar (defekasi) dengan tinja berbentuk cair atau setengah cair (setengah padat), kandungan air tinja lebih banyak dari biasanya lebih dari 200 gram atau 200 $\mathrm{ml} / 24$ jam. Defenisi lain memakai kriteria frekuensi, yaitu buang air besar encer setiap 4-6 jam sekali dapat/tanpa disertai lendir dan darah. $^{1,2}$
Diare umumnya disebabkan oleh kuman yang biasanya akan menyebar melalui fecal oral antara lain melalui makanan/minuman yang tercemar tinja atau kontak langsung dengan tinja penderita, penyebab lain juga bisa berupa penggunaan botol susu karena penggunaan botol ini mudah tercemar oleh kuman karena botol susah untuk dibersihkan. Adapun faktor lain, yaitu dapat berupa 
Studi penggunaan obat diare pada anak pasien rawat inap di RSUD Andi Djemma Masamba Kabupaten Luwu Utara periode Januari-Desember 2014

makanan yang kurang bergizi. Pada anakyang tidak diberi ASI resiko untuk menderita diare lebih besar dari pada anakyang diberi ASI penuh, dan kemungkinan menderita dehidrasi akan jauh lebih besar terjadi pada anakyang tidak diberikan ASI dibandingkan anakyang diberikan ASI. 3,4

Seiring dengan cepatnya perkembangan dalam era globalisasi, serta adanya transisi demografi dan epidemologi penyakit, maka masalah penyakit akibat perilaku dan perubahan gaya hidup yang berkaitan dengan perilaku dan sosial budaya cenderung akan semakin kompleks. Pada wilayah kota Masamba, masyarakat yang berperilaku hidup bersih dan sehat sebesar 69,33\%. Berdasarkan hasil riset kesehatan dasar 2010 secara nasional beberapa presentasi frekuensi penyakit diare pada anak adalah 552 (37,17 \%). Berdasarkan umur anak terbanyak pada umur 5-7 tahun (58,16 \%), berdasarkan jenis kelamin terbanyak pada anak jenis kelamin laki-laki $(58,51 \%)^{5}$

\section{Menurut WHO (World Health} Organization), 2013 kematian anak diseluruh dunia sebanyak 6,9 juta anak pada tahun 2011. Dari jumlah kematian didapat $18 \%$ kematian akibat dari penyakit diare.Kelompok umur yang tertinggi terkena diare di seluruh dunia yaitu umur di atas 5 tahun. Menurut Kementrian Kesehatan Republik Indonesia tahun 2013 angka kematian akibat diare di Indonesia pada tahun 2007 sebanyak 72 dari 4.032 penderita diare, tahun 2008 sebanyak 239 dari 8.133 penderita, tahun 2009 sebanyak 100 dari 5.756 penderita, dan tahun 2010 sebanyak 73 dari 4.204 penderita. Data terakhir tahun 2011 sebanyak 12 dari 3.003 penderita diare. Angka kematian akibat diare di Indonesia terjadi penurunan setiap tahunnya. ${ }^{6}$

UNICEF (United Nations International Childre's Emergency Fund) untuk urusan anak memperkirakan bahwa setiap 30 detik ada 1 anak yang meninggal dunia karena diare.Data Nasional Depkes menyebutkan setiap tahunnya di Indonesia 100.000 anak meninggal dunia karena diare. ${ }^{7}$

Adapun terapi pengobatan diare yaitu Terapi Farmakologi dan Non Farmakologi.Terapi Farmakologi meliputi pengurangan frekuensi diare dengan zat yang bersifat pengental. Contohnya kaolin, pectin, bismuth dan mengurangi penyerapan air diusus dengan zat pengecil pori-pori saluran cerna atau adstringensia.Contohnya 
Studi penggunaan obat diare pada anak pasien rawat inap di RSUD Andi Djemma Masamba Kabupaten Luwu Utara periode Januari-Desember 2014

tanin (dalam tea, daun jambu biji dan buah salak muda) serta mengurangi mortalitas atau gerakan usus dengan zat parasimpatolik. Contohnya golongan narkotik (kodein, loperamid).Terapi non farmakologi dalam upaya pencegahan dapat dilakukan dengan menghindari pemicu diare seperti perilaku pola hidup sehat.Namun, upaya yang paling penting dalam penanganan diare adalah mengoreksi kehilangan cairan dan elektrolit tubuh (dehidrasi) dengan penggantian cairan dan elektrolit secepat mungkin (rehidrasi). ${ }^{8}$

Walaupun penyakit diare pada anak tidak menyebabkan kematian secara langsung, tetapi dapat berakibat fatal bila penanganannya tidak tepat. Oleh karena itu perlu dilakukan penelitian mengenai gambaran penggunaan obat diare pada anak pasien rawat inap di RSUD Andi Djemma Masamba.

\section{METODE KERJA}

Jenis penelitian yang digunakan adalah penelitian deskriptif. Pengumpulan data diambil dari catatan medik secara retrospektif pada pasien rawat inap di RSUD Andi Djemma Masamba selama periode tahun 2014.

\section{Alat dan Bahan}

Bahan dan alat penelitian yang digunakan adalah isi dari catatan Rekam Medik Kesehatan (RMK) pasien diare di RSUD Andi Djemma Masamba selama periode tahun 2014.

\section{Prosedur Kerja}

\section{Tahap Persiapan}

Pada tahap persiapan diawali dengan studi kepustakaan, konsultasi dengan pembimbing, pengurusan izin penelitian. Pengurusan izin penelitian dilakukan dengan mengajukan surat permohonan izin penelitian pada pihak manajemen RSUD Andi Djemma Masamba. Selanjutnya dilakukan pengurusan Ethical Clearance kepada pihak Kedokteran Universitas Hasanuddin Makassar.

\section{Tahap Penelitian}

Tahap penelitian dimulai dari pengambilan dan pengelompokan sampel. Pengambilan sampel berdasarkan dari catatan medik pasien rawat inap di RSUD Andi Djemma Masamba sesuai kriteria inklusi. Setelah pengambilan sampel, dilakukan pengelompokan pasien yang menderita penyakit diare berdasarkan:

1. Profil pasien meliputi umur, berat badan, tinggi badan, jenis kelamin, tanda-tanda vital dan pemeriksaan tinja. 
Studi penggunaan obat diare pada anak pasien rawat inap di RSUD Andi Djemma Masamba Kabupaten Luwu Utara periode Januari-Desember 2014

2. Profil pengobatan meliputi jenis obat, dosis obat, frekuensi dan indikasi obat.

\section{HASIL PENELITIAN}

Hasil evaluasi data rekam medis di RSUD Andi Djemma Masamba Kabupaten Luwu Utara Periode Januari-Desember 2014 diperoleh data pasien yang didiagnosa diare rawat inap sebanyak 654 pasien, tetapi dalam penelitian ini data yang

diambil sebanyak 25 pasien berdasarkan perhitungan sampel minimum. ${ }^{9}$

Data pasien diare pada anak yang di rawat inap berdasarkan karakteristik pasien, terapi cairan pengganti, jenia obat, golongan obat, kelompok obat (generik dan non generik) serta berdasarkan ketepatan dosis obat dapat dilihat pada tabel dibawah ini:

Tabel 1 Karakteristik pasien diare pada anak rawat inap di RSUD Andi Djemma Masamba Kabupaten Luwu Utara Periode Januari-Desember 2014.

\begin{tabular}{|c|c|c|c|c|}
\hline Karakteristik & $\mathbf{N}(\%)$ & Min & Maks & Rata-rata $\pm(S D)$ \\
\hline $\begin{array}{c}\text { Jenis Kelamin } \\
\text { Laki-laki }\end{array}$ & $17(68,9)$ & - & - & \\
\hline Perempuan & $8(32,0)$ & - & - & \\
\hline $\begin{array}{c}\text { Usia (tahun) } \\
\text { Suhu Badan }\left({ }^{\circ} \mathrm{C}\right)\end{array}$ & $\begin{array}{l}25 \\
25\end{array}$ & $\begin{array}{c}1 \\
36\end{array}$ & $\begin{array}{l}12 \\
39\end{array}$ & $\begin{array}{l}3,40 \pm 3,175 \\
37,20 \pm, 866\end{array}$ \\
\hline LOS* $^{*}$ (hari) & 25 & 3 & 6 & $4,16 \pm 1,106$ \\
\hline
\end{tabular}

${ }^{*} \mathrm{SD}$ (Standar deviasi)

*LOS (Length of Stay)

Tabel 2. Klasifikasi pasien diare pada anak rawat inap berdasarkan terapi cairan pengganti Di RSUD Andi Djemma Masamba Kabupaten Luwu Utara Periode Januari-Desember 2014.

\begin{tabular}{ccc}
\hline Terapi cairan pengganti & Jumlah & Persentase \\
\hline KAEN 3B* & 17 & 68 \\
KAEN 4B & 5 & 20 \\
RL $^{*}$ & 3 & 12 \\
\hline Total & $\mathbf{2 5}$ & $\mathbf{1 0 0}$ \\
\hline
\end{tabular}


Studi penggunaan obat diare pada anak pasien rawat inap di RSUD Andi Djemma Masamba Kabupaten Luwu Utara periode Januari-Desember 2014

Tabel 3. Klasifikasi pasien diare pada anak berdasarkan jenis obat rawat inap di RSUD Andi Djemma Masamba Kabupaten Luwu Utara Periode JanuariDesember 2014.

\begin{tabular}{ccc}
\hline Jenis Obat & Jumlah & Persentase \\
\hline Zink suplemen & 21 & 30,4 \\
Parasetamol & 24 & 34,8 \\
Kotrimoksazol & 3 & 4,3 \\
Metronidazol & 10 & 14,5 \\
Probiotik & 2 & 2,9 \\
Metoklopramid & 1 & 1,4 \\
Amoxicilin & 2 & 2,9 \\
Gentamisin & 3 & 4,3 \\
Omeprazol & 2 & 2,9 \\
Cefotaxime & 1 & 1,4 \\
\hline Total & 69 & $\mathbf{1 0 0}$ \\
\hline
\end{tabular}

Tabel 4. Klasifikasi golongan obat pasien diare pada anak rawat inap di RSUD Andi Djemma Masamba Kabupaten Luwu Utara Periode Januari-Desember 2014.

\begin{tabular}{cc|c}
\hline Golongan Obat & Jumlah & Persentase \\
\hline Zink suplemen & 6 & 24,0 \\
Zink suplemen + antibiotik & 16 & 64,0 \\
Antibiotik & 2 & 8,0 \\
Antibiotik + antiemetik & 1 & 4,0 \\
\hline Total & $\mathbf{2 5}$ & $\mathbf{1 0 0}$ \\
\hline
\end{tabular}

Tabel 5 .Klasifikasi pasien diare pada anak rawat inap berdasarkan kelompok obat (generik dan non generik) di RSUD Andi Djemma Masamba Kabupaten Luwu Utara Periode Januari-Desember 2014.

\begin{tabular}{ccc}
\hline Kelompok obat & Jumlah & Persentase \\
\hline Generik & 63 & 58,9 \\
Non Generik & 44 & 41,1 \\
\hline Total & $\mathbf{1 0 7}$ & $\mathbf{1 0 0}$ \\
\hline
\end{tabular}

Tabel 6. Klasifikasi pasien diare pada anak rawat inap berdasarkan ketepatan dosis obat rawat inap di RSUD Andi Djemma Masamba Kabupaten Luwu Utara Periode Januari-Desember 2014.

\begin{tabular}{ccc}
\hline Ketepatan Dosis & Jumlah & Persentase \\
\hline Tepat & 85 & 98,8 \\
Tidak tepat & 1 & 1,2 \\
\hline Total & $\mathbf{8 6}$ & $\mathbf{1 0 0}$ \\
\hline
\end{tabular}


Studi penggunaan obat diare pada anak pasien rawat inap di RSUD Andi Djemma Masamba Kabupaten Luwu Utara periode Januari-Desember 2014

PEMBAHASAN

Pada penelitian ini telah dilakukan studi penggunaan obatdiare pada anak pasien rawat inap di RSUD Andi Djemma Masamba Kabupaten Luwu Utara Periode JanuariDesember 2014. Penelitian ini merupakan penelitian studi klinik (non eksperiemental) dengan metode deskriptif secara retrospektif terhadap gambaran penggunaan obat diare pada anak pasien rawat inap. Sampel yang diambil berupa data rekam medik pasien diare pada anak yang di rawat inap dengan jumlah kasus sebanyak 25 pasien.Pengumpulan data yang diperoleh kemudian di bandingkan dengan standar Drug Information Handbook.

Teknik pengambilan sampel dilakukan secara acak terkontrol. Sampel yang diambil mewakili populasi yang ada yang telah memenuhi kriteria inklusi, yaitu pasien yang di diagnosa menderita diare pada anak mulai umur 1-12 tahun, pasien rawat inap selama periode januaridesember 2014 dan pasien yang menggunakan satu atau lebih jenis obat. Berdasarkan hasil perhitungan rumus sampel. ${ }^{9}$

Hasil penelitian menunjukkan bahwa pasien diare pada anak rawatinap paling banyak laki-laki dibandingkan perempuan yang mengalami diare. Hal ini diduga karena aktifitas fisik yang membuat kondisi fisik tubuh cepat mengalami penurunan sistem kekebalan tubuh dan lebih berisiko terkena diare. Pasien diare memiliki kisaran umur 1 sampai 12 tahun, pada umur tersebut kelompok anak yang mulai aktif bermain dan beraktifitas baik didalam maupun diluar rumah, sehingga rentan terkena infeksi bakteri. Penyebab diare biasanya terjadi pada saat anak bermain dilingkungan yang kotor serta cara hidup yang kurang sehat dan bersih. ${ }^{10,11}$ Selain itu juga disebabkan oleh kuman yang biasanya akan menyebar melalui fecal oral antara lain melalui makanan/minuman yang tercemar tinja atau kontak langsung dengan tinja penderita. Salah satu manifestasi diare pada anak yaitu buang air besar yang lebih dari 3 kali dalam sehari, peningkatan suhu (demam), lemah, mual, dan muntah. Hasil penelitian yang diperoleh ratarata suhu tubuh dialami oleh pasien adalah $37,2^{\circ}$ C.Pada kondisi ini anak yang demam akan disertai dengan perasaan yang lemah atau lemas.Hal Ini dapat berhubungan dengan lama rawat inap, mulai dari 3 sampai 6 hari.Lama rawat inap tergantung seberapa parah penyakit yang diderita 
Studi penggunaan obat diare pada anak pasien rawat inap di RSUD Andi Djemma Masamba Kabupaten Luwu Utara periode Januari-Desember 2014

oleh pasien dan keefektifan obat yang diberikan kepada pasien. ${ }^{3}$

Pasien diare anak rawat inap mendapatkan terapi awal berupa cairan pengganti, terapi ini merupakan pertolongan pertama pada penderita yang sudah banyak kehilangan cairan pada saat masuk dan selama perawatan. Cairan pengganti yang diberikan seperti KAEN 3B, Ringer Lactat, dan KAEN 4B. Pemberian terapi cairan pengganti merupakan pengobatan utama pada penyakit diare yaitu dengan menggunakan terapi cairan dan elektrolit, seperti yang tertera pada tatalaksana penderita diare menurut Depertemen Kesehatan RI.

Obat-obatan yang diberikan pada pasien diare anak rawat inap adalah golongan zink dan antibiotik (Kotrimoksazol dan Metronidazol), selain itu diberikan obat seperti parasetamol, probiotik, amoxisilin, gentamisin, omeprazol, metoklopramid dan sefotaxim. Pemberian zink berfungsi mengurangi frekuensi buang air besar dan volume tinja sedangkan pemberian antibiotik dimaksudkan untuk mencegah atau menangani infeksi bakteri penyebab diare pada anak. Penggunaan antibiotik seperti kotrimoksazol, sefotaxim, amoxicillin, gentamisin, dan metronidazol merupakan antibiotik spektrum aktifitas luas dan efektif terhadap gram positif dan negatif termasuk E.coli yang merupakan salah satu penyebab utama diare. ${ }^{12}$ Pemberian Parasetamol dengan indikasi utama sebagai antipiretik atau penurun demam, dan metoklopramid sebagai antiemetik (antimuntah), anak yang muntah pada saat diare juga dapat mengakibatkan dehidrasi sehingga pemberian obat antiemetik selain menghentikan rasa mual juga dapat membantu dalam mengurangi kehilangan cairan pada saat diare. Sedangkan pemberian probiotik diindikasikan untuk memelihara kesehatan fungsi saluran cerna anak dan omeprazol digunakan untuk menurunkan kadar asam yang diproduksi di dalam lambung.

Pasien diare anak yang di rawat inap paling banyak menggunakan kelompok obat generik dari pada non generik. Hal ini disebabkan karena adanya ketentuan yang diwajibkan seluruh fasilitas kesehatan milik pemerintah untuk menggunakan obat generik dalam kegiatan pelayanan kesehatan sesuai dengan kebutuhan, dimana ketentuan tersebut tertuang dalam peraturan Menteri Kesehatan Nomor HK/02/Menkes/068/1/2010. Hal ini sudah sesuai dengan penggunaan obat generik di RSUD Andi Djemma 
Studi penggunaan obat diare pada anak pasien rawat inap di RSUD Andi Djemma Masamba Kabupaten Luwu Utara periode Januari-Desember 2014

Masmaba Kabupaten Luwu Utara lebih banyak dengan penggunaan obat generik.

Pasien diare anak rawat inap ditemukan adanya ketidaktepatan dosis obat dalam masa perawatan berupa metoklopramid. Pemberian metoklopramid seharusnya 0,1-0,5 $\mathrm{mg} / \mathrm{kg}$ tiap 6-8 jam sesuai dengan WHO model forumulary for children, Drug information Handbook maupun Pediatric medication handbook, namun pada data rekam medik yang diperoleh tidak sesuai.

Salah satu penyebab ketidakefektifan terapi obat adalah penggunaan dosis yang terlalu rendah ataupun terlalu tinggi untuk menghasilkan respon yang dikehendaki. ${ }^{7}$ Obat diare pada anak yang digunakan untuk terapi pasien yang memenuhi kriteria inklusi adalah Kotrimoksazol, Metronidazol, Parasetamol, Zink Suplemen, Probiotik, Amoxisilin, Gentamisin, Omeprazol, Sefotaxim. Obat-obat ini sudah sesuai dengan standar pemberian obat yang ditetapkan oleh WHO model forumulary for children, Drug information Handbook \& Pediatric medication handbook.

Adapun kelemahan dalam penelitian ini adalah kurang lengkapnya hasil tes laboratorium untuk pemeriksaan spesifik/pemeriksaan feses, dan kurang lengkap data rekam medik, selain itu peneliti juga tidak menghadapi pasien secara langsung sehingga tidak mengetahui dengan pasti kepatuhan pasien dalam mengkonsumsi obat yang diresepkan. Golongan dan jenis obat dievaluasi pada data rekam medik sehingga penggunaan sebenarnya tidak diketahui dengan pasti.

\section{KESIMPULAN}

Hasil penelitian yang dilakukan maka dapat disimpulkan bahwa penggunaan obat diare pada anak rawat inap di RSUD Andi Djemma Masamba Kabupten Luwu Utara Periode Januari-Desember 2014 adalah obat Antibiotik (Kotrimoksazol 4,3\%, Amoxisilin 2,9\%, Gentamisin 4,3\%, Sefotaksim 1,4\%),Antimikroba (Metronidazol 14,5\%), Zink suplemen 30,4\%, Probiotik 2,9\%, Antipiretik (Parasetamol 34,8\%), Antiemetik (Metoklopramid 1,5\%, dan Antidispepsia (Omeprazol 2,9\%).

\section{DAFTAR PUSTAKA}

1. Ardiansyah M. Medical Bedah Untuk Mahasiswa Cetakan Pertama. Jakarta : Diva Press; 2012.

2. Aru W, Sudoyo dkk. Ilmu Penyakit Dalam. Edisi Kelima. Jakarta : Interna Publishing; 2009. 
3. Depkes RI. Buku Pedoman Pelaksanaan Program P2 Diare. Jakarta : Ditjen P2M dan PL; 2011.

4. Dinkes Kota Makassar. Brosur Gerakan Makassar Sehat (GEMAS).10 Perilaku Hidup Bersih dan Sehat Di Rumah Tangga. Makassar; 2010.

5. Dlugosz, Cynthia K., , Rujukan Cepat Obat Tanpa Resep Untuk Prakisi, Jakarta: EGC; 2013.

6. Hidayat A, Aziz A. Pengantar IImu Kesehatan Anak Untuk Pendidikan Kebidanan. Edisi I. Jakarta : Salemba Medika; 2008.

7. Kementrian Kesehatan Indonesia. Pedoman Penanganan Anak Diare Di Rumah. Jakarta : Kementrian Kesehatan RI; 2013.
8. Notoatmodjo S. Pengantar Kesehatan Masyarakat dan IImu Perilaku Kesehatan. Yogyakarta : Andi Offset; 2003.

9. Pudjiadi S. Ilmu Gizi Klinis Pada Anak. Jakarta : FKUI; 2010

10. Puspitasari I.Cerdas Mengenali Penyakit dan Obat. Jakarta : Erlangga; 2010.

11. Sopiyudin MD. Besar sampel dan cara pengambilan sampel dalam penelitian kedokteran dan kesehatan edisi 3. Jakarta : Penerbit Salemba Medika; 2010.

12. Wulandari A. Penangan Diare di Rumah Tangga Merupakan Upaya Menekan Angka Kesakitan Diare Balita. Gorontalo : UNG; 2012. 